\title{
The Problem of Metanarratives in the Postmodern Age
}

\author{
Pavel E. Spivakovsky* \\ Moscow State University \\ 1-51 Leninskie Gory, 1 Humanities Building, \\ Moscow, 119991, Russia
}

Received 19.03.2015, received in revised form 04.04.2015, accepted 18.05.2015

The article is devoted to the analysis of metanarratives in contemporary art. Arguing with J.-F. Lyotard's famous statement that Postmodern is defined as incredulity towards metanarratives, the author asserts that in the Postmodern age metanarratives have not become a thing of the past, but acquired new features, thus becoming an essential component of postmodern aesthetics. Old metanarratives, which invariably carried ideological implications and thereby lost their relevance, are now replaced with new ones, associated with contemporary problematics and a particularly postmodern reception of the tragic. The author emphasizes the crucial character of a total revision of the axiological bases of modern society, seen as a way of liberating the perception of present problems from the burden of the old, noncurrent approaches, and clearing the way for the new metanarratives, free of the prejudices of the past.

The methodology of the article is based on an interdisciplinary approach. It involves explora-tion of metanarratives, expressed not only in fiction, but also in Willy Decker's staging of the opera "La Traviata," shown at the 2005 Salzburger Festspiele. Particular attention is given to the problem of the empty metaphysical center, which itself can be a source of pluralistic metanarration, free from ideology.

Keywords: metanarrative, postmodern, theory, tragic, Lyotard, Decker, Pelevin, Sorokin.

DOI: 10.17516/1997-1370-2015-8-7-1360-1365

Research area: philology.

Metanarration is a complex and paralogically comprehensive phenomenon. Thus, criticizing modern Russian metanarratives, M.N. Epstein relates their origin to throwbacks of totalitarian thinking. The scholar especially singles out cultivating religious faith; describing the ways of Russian metaculture in the same vein as The Rose of the World by Daniil Andreev does; Eurasianism and Russian cosmism (see: Epstein, 2015, 358-
360). All these examples describe metanarratives as ideological or authoritarian systems which require submission. Such "ideological correctness" is fraught with obvious dangers, but metanarration itself is noticeably wider than its utilitarian modus. For instance, non-ideological metanarrative (a tragic opposition to the repression of freedom or an unnatural way of life etc.) is not always associated with authoritarianism or

(c) Siberian Federal University. All rights reserved

* Corresponding author E-mail address: p.e.spiwakowsky@gmail.com 
violence. The ambiguity of this phenomenon gives birth to numerous problems.

Thus, at the starting point of postmodernist theory, the necessity to describe the limits of Postmodernism comes into being. Despite the fact that no general, more or less common definition has been suggested so far, we still have quite a number of expert opinions on this topic. Amongst others, there is a highly popular, and often taken as classical, statement by Jean-François Lyotard, who defines "postmodern as incredulity toward metanarratives" (Lyotard, 1984, xxiv), noticeably limiting the aesthetic range of postmodernist discourse, thus discarding religion, genuine seriousness and the tragic element. To be more precise, metanarration does not disappear completely within this Postmodern paradigm, but becomes a part of an ironical, travesty game instead, only to be compromised in the end.

As a rule, theoretical radicalization and a significant narrowing of limits are typical of Postmodern theory. This is also due to the fact that the theory is only slightly connected to Postmodern art, which creates a paralogically ambiguous situation whenever theoretical concepts turn out to be palpably more severe and radical than postmodernist artistic practice.

Olga Sedakova comments thus on the wide spreading of a radically postmodernist outlook and its consequences: "A representative international symposium The Modern imaginarium took place in May, 1999 in Ferrara. I also had the opportunity to lecture there $<\ldots>$. Many of the symposium's participants (including the pillars of postmodernism, its founding fathers) expressed distinctly negative judgments on contemporary - postmodernist imaginarium, if not simple tedium. Longing after the image, the symbol, longing after ethics, after a direct and strong expression: that is what could be heard in these words" (Sedakova, 2010, v. 4, 362).
However, instead of longing after what has been lost, it would perhaps be wiser to have a better look around us: what we see quite often happens to be much better, artistically richer and more interesting than expected. Actually, the theory itself is not so clear-cut. For example, dwelling on the tragic element in a classic Postmodern "poem" Moscow - Petushki by Venedikt Erofeev, M.N. Lipovetsky notices: "Erofeev's case is not unique: tragic overtones can clearly be heard in the first two novels by Sasha Sokolov, in S. Dovlatov's new autobiographism and in V. Sharov's historical fantasies, in works by J. Brodsky, Igor Kholin, Elena Shvarts, Viktor Krivulin, Alexander Eremenko; muted tragic elements appear (apophatically as M. Epstein would call it) in poems on cards by Lev Rubinstein and even in detective novels by B. Akunin. <.. > I would find it difficult to neglect tragic elements in such landmark works of Western Postmodernism as Lolita and Ada by V. Nabokov, The Name of the Rose and Foucault's Pendulum by U. Eco, Hopscotch by Julio Cortázar and Dictionary of the Khazars: A Lexicon Novel by Milorad Pavić" (Lipovetsky, 2008, 24).

In addition to these examples, one can mention the famous postmodernist novel Perfume by P. Süskind. There is also an interdisciplinary example - a world-famous performance of the opera La Traviata by Giuseppe Verdi, shown during the 2005 Salzburger Festspiele and directed by Willy Decker (the main parts played by Anna Netrebko and Rolando Villazón), which represents the postmodernist tragedy of conscience. This stage version is full of embodied metaphors, highly typical of contemporary postmodernist poetics. What is happening on stage breaks up with the traditional mimesis most radically by showing, in an extremely poignant way, life facts which wound the character's conscience. Besides, the conventional external attempts at concealing the shocking truth for 
the sake of decency are ignored. For example, the demimondaine Violetta is really a prostitute, but her way of life is seemingly quite decent. Using metaphor embodiment, Decker shows us a character who "actually" dresses up and acts like a prostitute, exposing in front of Violetta herself and in front of the spectators the dark side of the picture: one which could be guessed, but never seen in conventional visual and receptive modes, making it impossible to be shocked with it.

An important point in the performance is the substitution of the signified: at Flora's ball, the figure of dancing Violetta is revealed to be an exuberant porno transvestite wearing the same dress as her. A substitution of the signifier also occurs when the guests, enjoying themselves in an aggressive way, force a bull mask onto Alfred's face, while the travestied pseudoVioletta pointedly seeks to strike the prone Alfred with clock hands she tore off, showing in this deliberately kitschy way the public reproof of his allegedly immoral love for Violetta. At the same time Violetta gets the opportunity to look from the outside at her own actorial mask she previously judged adequately attractive, and it is a severe blow for her conscience.

When Violetta, dying of tuberculosis, turns to God, instead of an implicit "transcendent signified" we see Giuseppe Verdi, the explicit author of the opera. The visual substitution of the transcendental signifier in the show probably comes from the concept of an empty metaphysical center, typical for postmodern cultural tradition. However, what is this "emptiness" really? For an atheist with an anti-metaphysical way of thinking it is nothing, a figment; for a Jew, a Christian or a Muslim it means God, completely non-material in his nature; ${ }^{1}$ for a Buddhist it is the sacred Emptiness of Nirvana. The emptiness of the metaphysical center makes accepting it pluralistically and regardless of ideology possible. For example, if for a Christian the visual image of a genius, the author of the opera, refers to God towards whom Violetta turns, for an atheist this image is associated with a particular author's sphere of concepts, which gradually forms during the creation of La Traviata. Thus, it is not a rhizomatic chaos that turns out to be pluralistically non-authoritative, but the empty center itself. The whole performance proves to be a tragically universal anti-xenophobic anthropodicy, an antimimetic justification of "a fallen woman" and her self-sacrificing love. The so-called "broadening of artistic impressionability" in the Postmodern age creates a fundamentally new balance between the kitsch and the tragic. We apprehend the anti-mimetic reverse side of the events in all its dramatic and tragic complicacy, ignoring the external mimetic comme il faut simulation, and thus Violetta's tragic conflict with the social actant (which claims to be globally logocentric), gains symbolic, existential and cathartic depth. Thus a new and non-traditional version of the tragic turns out to be a powerful tool of contemporary art practice, including Russian literature.

It is no accident that eminent contemporary postmodernist poet Timur Kibirov, who also gravitates towards tragic metanarrative worldview in his poetry, and, in his later work, towards serious religiousness, highly appreciated the works of Dmitry Alexandrovich Prigov, a radical postmodernist, who used to reject mockingly all "traditional values."

As P. Sloterdijk claims, "from the dawn of time, human sentiment has regarded the old as the true, the new always as something questionable. This archaic feeling for truth had to be subdued by enlightenment, before we could see the new as the true." (Sloterdijk, 1987, 14). In fact, Prigov questions traditional axiology by forcing the reader to rethink epistemological (conventional) principles of the so-called axiomatic foundations. "Shaking" the unsteady foundations of Soviet epistemological patterns, Prigov tests other values 
of Russian social consciousness. It is this revision of the long-standing axiology that especially appeals to Kibirov.

They sit at the Arbat with their arms around each other.

They sit in each other's arms and read

Children of the Arbat. The dawn

rises over renewed Earth.

And Lenin lives. And the kiss of a girl's lips

is sweet. And Lenin lives! There will be

sausages in shops, and in our hearts

the love and flame of our youth!

And Dmitrii Alexanych, there he is!

(Kibirov, 2005, 831)

Absurd beliefs and expectations of Soviet people, repeated over and over again with insignificant temporal implications in the abovecited poem "Love, Komsomol and Spring," are waylaid by "predatory" Dmitry Alexanych, a sarcastic, sharp-tongued and relentlessly upright person, who scathes with irony all that is deceitful, deathful and illusive. For this reason, Kibirov's new sincerity and his postmodernist metanarratives wouldn't have been able to come into being without the "non-canonical classic", Prigov. Cleansed in the furnace of Postmodernism, metanarrative appears to be much more trustworthy...

Tragic elements are also present in V. Pelevin's later works. The short story Antiaircraft codes by Al-Efesbi and the novel S.N.U.F.F. are impregnated with deep tragedy, which was not characteristic of the writer earlier. Nevertheless, this tragic foray by no means indicates that Pelevin as an artist has suddenly become a passéiste: it is a new kind of tragedy. A fundamental difference between this new tragedy and the former tragic elements lies, as well as in Kibirov's poems, in the fact that the new one is influenced by pungent postmodernist irony which defaces false and deceitful metanarratives and thereby "apophatically" retains only what is real and true (as perceived by the author). At the same time, Pelevin's biased artistic concepts are visible in his abandoning former political indifference ${ }^{2}$ and assuming left-wing radical "anti-Western" and "anti-American" attitudes. Such ideological transformation has been rightfully denounced by critics, but the psychological depth and the artistic complexity of the novel S.N.U.F.F. deserve consideration and call for research. It is probably the most artistically impeccable of Pelevin's works.

The tragic end of Damilola Karpov, the main character, comes as a surprise to us. In the main part of the novel synecdochic features of Byzantium's almost universal hypocrisy prevail in the image of Damilola (and here Pelevin's biased ideological concepts are particularly apparent). However, after losing his lover-the robot Kaia (in fact, this robotic girl is the perfect representation of an ideal woman), Damilola, exactly like Spiridon in The First Circle by A. Solzhenitsyn, who, allegedly for his family's sake, did dreadful things, unexpectedly renounces Byzantinium's lie: “The whole Big Byz thought they were fulfilling Manitou's will, but then-why is our world falling apart, why does the Universe crumble under our feet? How should a deeply religious person interpret this?

Perhaps Manitou does not want us to think that we know him in person any more, and especially that we are aware of his plans and secrets.

Manitou does not want to have professional servants and messengers, and our sacraments cause aversion in him. He does not want us to nourish him with somebody else's blood, offering him our legally flawless gerontophilic snuffs. How can he love us when our own appliances for voluptuousness, made in the image and likeness of us, leave us? Why does he need a world where 
only a rubber doll is capable of unconditional love?

We are appalling in Manitou's eyes, and I am glad to reach the time when I am not afraid to say it aloud. From now on, everything will be different. And only Manitou himself knows, how" (Pelevin, 2012, 474-475).

Damilola's choice of an imminent death is caused not only by his unhappy love for Kaia, but also by a general disillusionment with the ontological project of the Big Byz itself. A similarly unexpected and therefore shocking end is present in V. Sorokin's short story, $A$ Month in Dachau. The main character yields to all ideological and ethical temptations of love for a female SS officer, Margarita, and then, being at the peak of a "Nazi love idyll," suddenly renounces everything: a high standing in the National Socialist world, which he bought at a high price, betraying everyone he had loved before, including his mother; love, involving reading on human heads and having a "superhuman" cannibal feast; even his own life. This costly "happiness" turns out to be meaningless and almost unbearable when founded on blood and suffering of the others.

Generally speaking, the purification of metanarratives represents, in its own way, a $\mu \varepsilon \tau \alpha$ óvol $\alpha$ for contemporary culture. Ironically avoiding canonized metanarratives of the past, which have already lost their significance and sincerity and become prey to epigones, postmodern culture inevitably creates an innovative metanarration, capable of conveying the tragic depth of our extraordinary, formidable and beautiful era.

\footnotetext{
Thus, Olga Sedakova writes "of light from Nothing” (Sedakova, 2010, t. 1, 159).

2 See the epigraph to the novel Generation " $P$ ", using lyrics from Democracy by Leonard Cohen:

I'm sentimental, if you know what I mean;

I love the country but I can't stand the scene.

And I'm neither left or right.

I'm just staying home tonight,

Getting lost in that hopeless little screen (Pelevin, 2000, 9).
}

\section{References}

1. Kibirov, T. Iu. (2005) Stikhi [Poems]. M.: Vremia. 511 p.

2. Lyotard, J.-F. (1984) The Postmodern Condition. Manchester: Manchester University Press. $110 \mathrm{p}$.

3. Lipovetsky, M.N. (2008) Paralogii: transformacii (post)modernistskogo diskursa v kul'ture 1920-2000-kh godov [Paralogies: The Transformations of (Post)modern Discourse in Culture, 19202000]. M.: Novoe literaturnoe obozrenie. 840 p.

4. Pelevin, V.O. (2000) Generation "P". M.: Vagrius. 335 p.

5. Pelevin, V.O. (2012) S.N.U.F.F. M.: Eksmo. 478 p.

6. Sedakova, O.A. (2010) Sobr. soch.: v 4 t. [Collected Works in 4 Volumes]. M.: Universitet D. Pozharskogo. V. 1-4.

7. Sloterdijk, P. (1987) Critique of Cynical Reason. Minneapolis: University of Minnesota Press. $558 \mathrm{p}$.

8. Epstein, M.N. (2015) Ironiia ideala: paradoksy russkoi literatury [Irony of the Ideal: Paradoxes of Russian Literature]. M.: Novoe literaturnoe obozrenie. 382 p. 


\section{Проблемы метанаррации}

\section{в эпоху постмодерна}

\section{П.Е. СПиваковский \\ Московский государственный университет Россия, 119991, Москва, Ленинские горы, 1-51, 1 Гуманитарный корпус}

В статье проанализирована роль метанарративов в современной художественной практике. Полемизируя со знаменитыми словами Ж.-Ф. Лиотара о недоверии постмодернистской традиции к метарассказам, автор утверждает, что метанаррация в эпоху постмодерна не только не ушла в прошлое, но и приобрела новые черты, становясь важным элементом постмодернистской эстетики. На место прежних, потерявиих актуальность идеологизированных метанарративов приходят новые, связанные с современной проблематикой и особым, постмодернистским восприятием трагического. $B$ статье подчёркивается, что тотальная ревизия аксиологических оснований всего что нас окружает абсолютно необходима: она освобождает восприятие современных проблем от груза старых, потерявших актуальность подходов и в то же время открывает дорогу для новой метанаррации, очищенной от ложного пафоса и предрассудков прошлого.

Методологически статья строится на междисииплинарной основе. В ней проанализировань не только литературные метанарративы, но и постановка оперы «Травиата», осуществлённая на Зальцбургском фестивале 2005 г. Вилли Деккером. Особое внимание уделено проблеме пустого метафизического иентра, который сампо себеможет быть источником деидеологизированной плюралистической метанаррации.

Ключевые слова: метанарратив, постмодерн, теория, трагическое, Лиотар, Деккер, Пелевин, Сорокин.

Научная специальность: 10.00.00 - филологические науки. 